Abant Tıp Dergisi

Araştırma Makalesi / Cilt 10 Sayı 3 Yıl 2021
Abant Medical Journal

Research Article / Volume 10 Issue 3 Year 2021

\title{
Genel Anestezi Altında Alınan Gastrointestinal Tümör Cerrahisi Geçiren Hastalarda Lomber-Epidural Analjezinin Postoperatif Analjezi Üzerine Etkileri Effects of Lumbar-Epidural Analgesia on Postoperative Analgesia in Patients Undergoing Gastrointestinal Tumor Surgery Under General Anesthesia
} Esra AKTiZ BIÇAK (D), Hakan AKELMA (D), Mustafa BIÇAK (D), Fikret SALIK (iD), Sedat KAYA (D)

Sağlık Bilimleri Üniversitesi Gazi Yaşargil Eğitim ve Araştırma Hastanesi, Diyarbakır, Türkiye

Öz

GíRiş ve AMAÇ: Bu çalışmada gastrointestinal malignite cerrahisi geçiren hastalarda genel anestezi ve genel anesteziye ek epidural analjezi uygulamasının intraoperatif hemodinami, derlenme, analjezik tüketimi ile postoperatif vizuel analog skala (VAS) skorları ve hastane yatış sürelerine olan etkilerini karşılaştırdık.

YÖNTEM ve GEREÇLER: Prospektif gözlemsel olarak yapılan çalışmaya 18-80 yaşları arasında, Amerikan Society of Anesthesiologist (ASA) 1-3 olan ve genel anestezi altında gastrointestinal tümör cerrahisi yapılan 28 hasta dâhil edildi. Hastalar randomize olarak iki gruba ayrıldı; Grup 1 (epidural analjezi uygulanan hastalar $n=14$ ) ve Grup 2 (epidural analjezi uygulanmayan hastalar $n=14$ ). Hastaların yaş, beden kitle indeksi, ek hastalıkları, anestezi süresi, intraoperatif hemodinamik verileri, operasyon süresi, kullanılan opioid miktarı, mobilizasyon süreleri, hastanede yatış süreleri ve postop gözlenen komplikasyonlar kaydedildi. Hastaların ALDRETE skoru ve 30 dakika, 1, 2, 6, 12, 24 ve 48. saatlerdeki VAS değerleri kaydedildi.

BULGULAR: Hastaların Aldrete skorları epidural uygulanan grupta epidural uygulanmayan gruba göre istatistiksel olarak anlamlı derecede yüksek bulundu ( $p$ değeri 10., 20. ve 30.dk sırasıyla 0.001, 0.000, 0.002). 30.dk., 1., 2., 6., 12., 24. ve 48. saat VAS değerleri ise epidural uygulanan grupta epidural uygulanmayan gruba göre istatistiksel olarak anlamlı derecede düşük saptandı (tüm ölçüm saatlerinde $p$ değeri=0.000). Mobilizasyon süresi epidural uygulanan grupta epidural uygulanmayan gruba göre istatistiksel olarak anlamlı derecede daha düşüktü ( $p$ değeri=0.000).

TARTIŞMA ve SONUÇ: Gastrointestinal cerrahide epidural analjezinin daha stabil hemodinamik, erken derlenme kriterleri, düşük yan etki profili ve postoperatif erken mobilizasyon sağladığını saptadık.

Anahtar Kelimeler: Genel anestezi, gastrointestinal tümör, cerrahi, lomber-epidural, analjezi

\section{Abstract}

INTRODUCTION: The present study we aimed to compare the effects of general anesthesia and general anesthesia + epidural analgesia on intra-operative hemodynamics, recovery, analgesic consumption, postoperative visual analog scale (VAS) scores and hospitalization times in patients undergoing gastrointestinal malignancy surgery.

METHODS: A prospective observational study included 28 patients aged 18-80, who were the American Society of Anesthesiologist (ASA) 1-3 and underwent gastrointestinal tumor surgery under general anesthesia. Twenty-eight patients randomly divided into two groups; Group 1 (patients with epidural analgesia $n=14$ ) and Group 2 (patients without epidural analgesia $n=14$ ). Age, body mass index, comorbid diseases, duration of anesthesia, duration of operation, mobilization time, duration of hospitalization, intraoperative hemodynamic data and post-op complications of all patients were recorded by the researcher. ALDRETE scores of the patients and VAS values of the patients on the 30 minutes, 1, 2, 6, 12, 24 and 48 hours were recorded by the researcher.

RESULTS: Aldrete scores of the patients were found to be statistically significantly higher in the epidural group compared to the non-epidural group ( $p$ values of 10., 20. and $30 . \mathrm{min}$ respectively $0.001,0.000,0.002$ ). VAS scores of 30.min., 1., 2., 6., 12., 24. ve 48. hour were statistically significantly lower in the epidural group than in the nonepidural group (at all measurement times $p$ value $=0.000$ ). Mobilization time was statistically significantly lower in the epidural group than the non-epidural group ( $p$ value=0.000).

DISCUSSION and CONCLUSION: As a result, in this study we found that epidural analgesia in gastrointestinal surgery provides more hemodynamic stabilization, early recovery, low side effect profile, in addition to early postoperative mobilization and shorter duration of hospitalization.

Keywords: General anesthesia, gastrointestinal tumor, surgery, lumbar-epidural, analgesia 
olabileceği için her hastada mutlaka tedavi edilmelidir. Ağrı fizyopatolojisindeki son gelişmeler ışığında postoperatif ağrıya neden olan santral nöral hipereksitabilitenin azaltılabileceği veya önlenebileceği teorisi üzerinde durulmaktadır (1).

Günümüzde daha iyi anlaşılan ağrı mekanizmaları artık, spinal kordda bir araya gelen santral sinir sisteminin farklı düzeylerindeki eksitatör ve inhibitör sistemler arasındaki kompleks etkileşim olarak ele alınmaktadır. $\mathrm{Bu}$ süreçlerin anlaşılmasının bir sonucu olarak birden fazla bölgenin hedef alınması analjezik etkinin artırılmasını, yan etkilerin azaltılmasını ve daha iyi sonuçlar elde edilmesini sağlar. Günümüzde majör cerrahi vakalarının önemli bir bölümünde en iyi ağrı kontrolünün multimodal veya dengeli analjezi ile sağlanabildiği kabul edilmektedir (2).

Postoperatif hiperaljezinin gelişmesinden iki etken sorumludur. Birinci etken cerrahi girişim iken ikinci etken peroperatif kullanılan opioidlerdir (3). Opioide bağlı hiperaljezi, opioid maruziyetine bağlı nosiseptif sensitizasyonu olup perioperatif dönemde kısa etkili opioid kullanımı sonucu gelişebilmektedir (4-6).

Multimodal yaklaşımda kullanılan lokal anestezikler, nonsteroid antiinflamatuar ilaçlar (NSAii), siklooksigenaz 2 inhibitörleri, asetaminofen, ketamin, $\alpha 2$ agonistler gibi nonopioid analjezikler opioid analjezikleri destekler ve opioidlere bağlı yan etkileri azaltırlar. Doku infiltrasyonu ve yara yerine lokal anestezik ilaç uygulamaları da bu amaçla önerilmiştir $(7,8)$.

Spinal anestezi sonrası postoperatif baş ağrısı gelişebileceğinden epidural analjezi tercih edilebilir. Batın cerrahilerinde uzun süreli postoperatif analjezi ihtiyacı nedeniyle tek seferde yapılan epidural enjeksiyon tekniğine kıyasla epidural katater daha çok kullanılmaktadır (1).

Bu çalışmada gastrointestinal tümör cerrahisi geçiren hastalarda genel anestezi ve genel anestezi+lomber epidural analjezi uygulamalarının intraoperatif ve postoperatif analjezi ve opioid tüketimi üzerine etkilerini karşılaştırmayı amaçladık.

\section{GEREÇ ve YÖNTEMLER}

Çalışmamı prospektif gözlemsel bir çalışma olarak planlandı. Çalışmaya 01.01.2019-01.01.20 tarihleri arasında 18-80 yaşları arasında, Amerikan Society of Anesthesiologist (ASA) 1-3 olan ve genel anestezi altında gastrointestinal tümör cerrahisi yapılan 28 hasta dâhil edildi.

18 yaşından küçük, 80 yaşından büyük hastalar; morfin, hidromorfon, lidokain, bupivakain ve fentanile karşı alerjik reaksiyon öyküsü olan; vertebra deformitesi olan, epidural aneljeziyi kabul etmeyen; işlem bölgesinde enfeksiyonu olan, koagülopati olan veya cerrahi teknik nedeniyle antikoagülan kullanması gereken hastalar, epidural uygulaması başarısız olan hastalar ve madde bağımlılık öyküsü olan hastalar çalışmaya dâhil edilmedi.

Tüm hastalar cerrahi işlem öncesi anestezi polikliniğinde deneyimli bir anestezi uzmanı tarafından değerlendirildi. Hastalara yapılacak işlem hakkında bilgi verildi ve hastalardan yazılı bilgilendirilmiş onam alındı. Postoperatif ağrının değerlendirilmesinde kullanılacak VAS skorlaması hakkında ayrıntılı bilgi verildi (Şekil 1). Hastaların ulaşabilecekleri bir araştırmacının telefon numarası verildi.

Hastalara operasyon sabahı 18-20 G periferik venöz damar yolu açılarak cerrahiden bir saat önce intravenöz yolla premedikasyon amaçlı 0,07 $\mathrm{mg} / \mathrm{kg}$ dozunda midazolam (Dormicum, amp, 5 $\mathrm{mg}$, Roche, İstanbul, Türkiye) uygulandı. Hastalar operasyon günü en az 8 saatlik açlık süresiyle ameliyat masasına alındı. Tüm hastalara rutin olarak noninvaziv arteryel kan basıncı, elektrokardiyogram, oksijen saturasyonu monitorizasyonu uygulandı. Hastalara işlem boyunca $10 \mathrm{ml} / \mathrm{kg} /$ saat serum fizyolojik verildi. 
Hastalar randomize olarak iki gruba ayrıldı; Grup1 (epidural analjezi uygulanan hastalar $n=14$ ) ve Grup 2 (epidural analjezi uygulanmayan hastalar $n=14)$.

Grup 1'deki hastalar genel anestezi uygulamasından önce epidural katater yerleştirmek amacıyla oturur pozisyona alındı. İşlem bölgesi steril şartlarda temizlendikten sonra steril örtü ile örtüldü. Orta hat, lomber 3-4 veya 4-5'inci intervertebral aralık belirlendi. 18 gouge Tuohy iğnesiyle direnç kaybı tekniği epidural alana girildi. 25 gauge epidural katater epidural alana ilerletildi (Perifix Soft Tip 701 Filter set, Braun Melsungen AG, Germany). Katater epidural mesafede 4-6 cm kalacak şekilde tespit edildi ve test dozu yapıldı.

Grup 2 'deki hastalara epidural katater uygulaması yapılmadı. Hastaların tümüne anestezi indüksiyonu amacıyla $2 \mathrm{mg} / \mathrm{kg}$ propofol (Propofol \%1 Fresenius, Fresenius Kabi Deutschland $\mathrm{GmbH}), 100$ mcq fentanyl (Fentanyl Citrate, amp, Abbott, İstanbul, Türkiye) ve 0,6 $\mathrm{mg} / \mathrm{kg}$ roküronyum (Esmeron $50 \mathrm{mg} / 5 \mathrm{ml} \mathrm{N} . \mathrm{V}$. Organon, Oss, Hollanda) uygulandı. Yeterli kas gevşemesi sağlandıktan sonra uygun boyutta tüp seçilerek trakeal entübasyon gerçekleştirildi. Anestezi idamesi \%50 sevoflorane (Sevorane, Likid, Abbott Laboratories, England) ve \%50 oksijen karışımıyla sağlandı.

Tüm hastalara radyal arter kanülasyonu yapılarak cerrahi süresince invaziv arterial basınç takibi, sağ internal juguler venden $7 f$ santral venöz kateterizasyon yapıldı.

Grup 1'deki hastalara genel anestezi uygulaması sonrasında analjezi amaçlı hasta kontrollü analjezi (PCA) cihazı takıldı ve 100 mg izobarik bupivacain+150 mcq fentanyl+serum fizyolojik solüsyonu (toplam $100 \mathrm{ml}$ ) hazırlandı. $10 \mathrm{ml}$ loading dozu, $10 \mathrm{ml}$ PCA dozu, 20 dakika kilit süresi, $80 \mathrm{ml} 4$ saatlik limit ve $10 \mathrm{ml}$ bazal infüzyon dozu ayarlandı. Hastaların cerrahi süresince bazal tansiyon arterial değerlerinden \%20 ve üzeri artış olması halinde 10 mI PCA dozu uygulandı.

Grup 2'deki hastalara cerrahi bitiminden 30 dakika önce postoperatif analjezi amaçlı $100 \mathrm{mg}$ tramadol ve $1 \mathrm{gr}$ parasetamol uygulandı. Hastaların cerrahi süresince bazal tansiyon arterial değerlerinden \%20 ve üzeri artış olması halinde $100 \mathrm{mcq}$ fentanyl intravenöz yolla uygulandı ve intraoperatif kullanılan opioid miktarı olarak kayıt altına alındı. Postoperatif dönemde 6 saat arayla 100 mg tramadol ve $1 \mathrm{gr}$ parasetamol uygulanması order edildi.

Tüm hastaların yaş, beden kitle indeksi (BMi), ek hastalıkları, anestezi süresi, operasyon süresi, mobilizasyon süreleri, hastanede yatış süreleri ve postoperatif komplikasyonlar kayıt altına alındı.

Epidural girişim öncesi ve sonrası; indüksiyon öncesi, indüksiyon sonrası, entübasyon sonrası, cilt insizyonu sonrası, operasyonun 30. dakikası ile 1 ve 2 . saatinde ve ekstübasyon sonrasında $\mathrm{KAH}, \mathrm{SAB}, \mathrm{DAB}$ değerleri kaydedildi.

Operasyon bitiminde ekstübe edilen hastalar postoperatif derlenme odasına (PACU) alındı. Hastaların 30 dakika, 1, 2, 6, 12, 24 ve 48 . saatlerdeki VAS değerleri araştırmacı tarafından kayıt altına alındı. Tüm hastalara VAS>3 olunca intramusküler diclofenac sodyum uygulandı.

Hastaların derlenme süreleri ALDRETE skorlama sistemiyle değerlendirilip kayıt altına alındı (Her bir bulgu için verilen puanların toplamının, derlenme hızı ve kalitesini gösterdiği bu değerlendirmede, 10 puan tam derlenme olarak kabul edildi. Aktivite: Bütün ekstremiteleri hareket ettirebiliyor ise 2 puan, iki ekstremiteyi hareket ettirebiliyor ise 1 puan, ekstremitede hareket yok ise 0 puan; Solunum: Solunum derinliği yeterli, öksürebiliyor ise 2 puan, solunum hareketleri yüzeyel, dispne veya taşipne var ise 1 puan, apneik veya mekanik ventilatörde ise 0 puan; Arteriyel kan basıncı: Normal değerden sapma <\% 10 ise 2 puan, normal değerden sapma <\% $11-20$ ise 1 puan, normal değerden sapma >\% 21 ise 0 puan; Bilinç 
durumu: Tamamen açık ise 2 puan, verbal uyarıya refleks yanıt var ise 1 puan, verbal uyarıya refleks yanit yok ise 0 puan; Periferik oksijen satürasyonu: Oda havasında SpO2>\% 92 ise 2 puan, SpO2>\% 90 sürdürebilmek için O2 desteği gerekliliği varsa 1 puan, sürekli $\mathrm{O} 2$ desteği ile $\mathrm{SpO} 2<\% 92$ ise 0 puan olarak değerlendirildi) (Şekil 2).

İstatistiksel analizler için SPSS 16.0 for Windows programı (SPSS Inc., Chicago, IL, USA) kullanıldı. Istatistiksel olarak sayısal veriler ortalama ve standart sapma; kategorik veriler ise frekans ve yüzde olarak ifade edildi. Gruplardaki kategorik verilerin karşılaştırılması ki kare testi ile yapıldı, sonuçlar \%n olarak verildi. Numerik verilerin normallik dağılımına uyup uymadığı KolmogorovSmirnov testi ile değerlendirildi. Normallik dağılımına uyan veriler student $t$ testi ile değerlendirilirken, normallik dağııımına uymayan verilerin karşılaştırılmasında Mann Whitney-U testi kullanıldı. Tüm karşılaştırmalarda $p<0.05$ anlamlı kabul edildi.

\section{BULGULAR}

Hastaların ortalama yaşı $58,7 \pm 12,3$ yıl olarak bulundu. 14 hasta erkek ve 14 hasta kadın idi. Hastaların ortalama BMI değeri $24,3 \pm 4,4$ idi (Tablo 1). 1 hastada diyabetes mellitus, 6 hastada hipertansiyon ve 6 hastada kronik obstriktif akciğer hastalığı mevcuttu. Gruplar arasında yaş, cinsiyet, BMI ve komorbidite varlığı açısından istatistiksel olarak anlamlı fark saptanmadı ( $p$ değerleri sırasıyla $0.337,0.149,0.438$ ve 1.000 )

Hastaların ortalama Aldrete skorları epidural uygulanan grupta 10. dakikada 7,79 $\pm 0,8,20$. dakikada $8,79 \pm 0,6,30$. dakikada $9,14 \pm 0,5$ idi. Epidural uygulanmayan grupta ise sirasiyla $6,71 \pm 0,46,7,64 \pm 0,4$ ve $8,36 \pm 0,4$ idi. Hastaların Aldrete skorları 10., 20. ve $30 . \mathrm{dk}^{\prime} \mathrm{da}$ epidural uygulanan grupta epidural uygulanmayan gruba göre istatistiksel olarak anlamlı derecede yüksek bulundu ( $p$ değerleri sırasıyla $0.001,0.000$ ve 0.002). Hastaların ortalama VAS değerleri epidural uygulanan grupta 30 . dakikada $3,0 \pm 0,8$,
1. saatte $2,93 \pm 0,8,2$. saatte $2,64 \pm 0,9,6$. saatte $2,36 \pm 0,6,12$. saatte $1,79 \pm 0,6,24$. saatte $1,29 \pm 0,6$, 48. saatte $1,14 \pm 0,5$ idi. Epidural

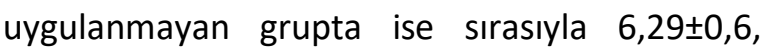
$5,79 \pm 1,0,5,00 \pm 1,1,4,64 \pm 0,7,4,00 \pm 0,8,3,71 \pm 0,6$ ve $3,29 \pm 0,9$ idi. VAS değerleri epidural uygulanan grupta epidural uygulanmayan gruba göre istatistiksel olarak anlamlı derecede düşük saptandı (tüm ölçüm saatlerinde $p$ değeri=0.000). Ortalama mobilizasyon süresi epidural uygulanan grupta $12,36 \pm 2,8$ saat ve epidural uygulanmayan grupta $24,71 \pm 3,1$ saat olarak bulundu. Mobilizasyon süresi epidural uygulanan grupta epidural uygulanmayan gruba göre istatistiksel olarak anlamlı derecede daha düşüktü ( $p$ değeri=0.000) (Tablo 2).

Hastaların intraoperatif opioid tüketimi epidural uygulanan grupta $100 \pm 0,0$ ve uygulanmayan grupta $246,4 \pm 21,5$ idi ve bu fark istatistiksel olarak anlamlı derecede daha düşük saptandı ( $p$ değeri=0.000) (Tablo 2).

Hastaların sistolik arter basınç değerleri incelendiğinde; cilt insizyonu sonrası, operasyonun 120. dk. ve ekstübasyon sonrası gruplar arasında istatistiksel olarak anlamlı bir fark olduğu saptandı ( $p$ değerleri sırasıyla 0.003, 0.039 ve 0.031 ) (Tablo 3).

Hastaların diastolik arter basınç değerleri epidural incelendiğinde; cilt insizyonu sonrası, operasyonun 30. dk., 60. dk. ve ekstübasyon sonrası gruplar arasında istatistiksel olarak anlamlı bir fark olduğu saptandı ( $p$ değerleri sırasıyla $0.009,0.032,0.045$ ve 0.031 ) (Tablo 4).

Hastaların kalp atım hızı değerlerinin epidural uygulanan ve uygulanmayanlara göre incelendiğinde istatistiksel olarak anlamlı bir fark olmadığı görüldü (Tablo 5).

\section{TARTIŞMA}

Postoperatif ağrı tedavisinin amacı, ağrı kontrolünün yanı sıra solunum ve gastrointestinal sistem fonksiyonlarının bozulmasını önlemek ve 
erken mobilizasyona olanak sağlamaktır. Cerrahi travmaya verilen stres yanıt ve ağrı iyileşmeyi geciktirip morbidite ve mortaliteyi arttırmaktadır. Postoperatif dönemde kesintisiz devam eden dengeli bir analjezi, stres yanıtın oluşturacağı zararlı etkileri azaltmaktadır. Bu nedenle katater aracılığı ile sağlanan sürekli epidural analjezi sıklıkla tercih edilen bir tekniktir $(9,10)$.

Carli ve ark. kolorektal cerrahiye alınan 42 olguda yaptıkları bir çalışmada iv morfin ile torasik epidural bupivakain+fentanil karışımından oluşan hasta kontrollü analjeziyi (HKA) gastrointestinal fonksiyonlar, hastanede kalış süresi ve analjezi kalitesi açısından karşılaştırmışlardır (11). Torasik epiduralden bupivakain ve fentanilin birlikte uygulanmasının dengeli bir analjezi oluşturduğunu ve yan etkileri azalttığını bildirmişlerdir. Ancak her iki grupta hastanede kalış süresi ve komplikasyon sayısını benzer olarak bulmuşlardır. Bu durum, çalışmamızda epidural fentanyl-bupivakain kombinasyonu tercihimizin doğru olduğunu destekler yöndedir. $\mathrm{Bu}$ nedenle çalışmamızda opioid ajan olarak fentanyl kullanmayı tercih ettik.

Postoperatif ağrı kontrolünün sağlanması erken mobilizasyon, hastanede daha kısa kalım süresi, hastane maliyetinde azalma ve hasta memnuniyetinde artış sağlar (12). Postoperatif ağrı yönetiminde amaç; yeterli analjezi sağlarken oluşabilecek yan etkileri de minimize etmektir (13). Ancak her hasta için standart bir tedavi yöntemi olmadığı gibi yan etkilerden arındırılmış optimal bir ilaç ve yöntem de henüz bulunamamıştır (13).

Postoperatif ağrı yönetiminde tek bir ajanla sağlanan analjezi yeterince efektif olmayabilir. Bu nedenle postoperatif analjezide birçok ilaç ve yöntemin kombine edildiği "multimodal analjezi" yöntemleri kullanılmaktadır (14). Multimodal analjezi; değişik etki mekanizmasına sahip bir veya daha fazla analjezik ajan ve analjezi yönteminin kombine edilmesidir. Bu yöntemle, additif ve sinerjistik etki sağlanarak kullanılan ajanların dozları ve yan etkilerinin azaltılması, analjezik etkinliğin arttırılması sağlanır (13). Çalışmamızda postoperatif ağrının kontrolünde lokal anestezik ajan ve opioid kombinasyonunu tercih ederek minimum yan etki profiliyle maksimum analjezi sağlamayı amaçladık.

Yapılan çalışmalarda batın cerrahilerinde genel anesteziye ek olarak epidural anestezi uygulanmasının analjezik etkisinden dolayı SAB ve $D A B$ değerlerini düşürerek daha dengeli hemodinami sağladığı bildirilmiştir $(15,16)$. Alagöz ve ark. pulmoner rezeksiyon yapılan 30 hastada TiVA ile epidural kateterden bupivakain infüzyonunu karşılaştırmışlar ve epidural ilaç infüzyonu uyguladıkları hastalarda DAB değerlerini anlamlı düzeyde düşük bulmuşlardır (17). Biz de önceki çalışmalara paralel olarak genel anesteziye ek olarak epidural anestezi uygulanan hastalarda cilt insizyonu sonrası intraoperatif dönemde daha dengeli hemodinami ve daha düşük $S A B$ ve $D A B$ değerleri tespit ettik. Bu farkın epidural ilaç uygulamasının neden olduğu sempatik- duysal blokajdan ve uygulama sırasında yapılan açıklamanın hastadaki postoperatif ağrıya bağlı oluşan anksiyetenin giderilmesine katkısından kaynaklandığını düşünmekteyiz.

Özdilmaç ve arkadaşları alt batın cerrahisinde iv morfin ile epidural kataterden morfin uygulamalarını karşılaştırmışlardır ve gruplar arasında $\mathrm{OAB}$ ve $\mathrm{KAH}$ değerleri açısından istatistiksel olarak anlamlı farklılık bulamamışladır (18). Bizim çalışmamızda da bu çalışmaya benzer olarak gruplar arasında $\mathrm{KAH}$ değerleri istatistiksel olarak benzerdi.

Gastrointestinal malignite cerrahisinde postoperatif ağrı yönetimi hem klinisyenler hem de hastalar için önemli bir sorundur. Çalışmamızda gruplar kendi içinde kıyaslandığında postoperatif olarak epidural anestezi uygulanan hastalarda ilk 12 saatteki VAS ağrı skorları anlamlı derecede düşüktü. Tulgar ve ark. tek bir cerrahi seansta çoklu abdominal 
prosedür uygulanan 3 hastada epidural anestezi uyguladılar (19). Bu çalışmada VAS skor farkı 24 saatte istatistiksel olarak anlamlı değildi ve bunun tek bir enjeksiyonun kullanılmasıyla ilişkili olduğunu düşünmekteyiz. Katater yerleşimi ve aralıklı bolus enjeksiyonu analjezi süresini uzatabilir ve daha uzun sürede ağrı skorlarını düşürebilir. Bu veriler, epidural anestezinin postoperatif ağrı kontrolü için başarılı bir teknik olduğunu göstermektedir.

Postoperatif ağrı; morbiditenin artmasına, fiziksel fonksiyon ve yaşam kalitesinin bozulmasına, iyileşmenin yavaşlamasına, hastane yatış sırasında ve sonrasında uzun süreli opioid kullanılmasına ve artan bakım maliyetine yol açar. Ayrıca artan postoperatif ağrı, ameliyattan sonra aylarca sürebilen kalıcı ağrıyı tetikleyebilir (20). Postoperatif yüksek ağrı düzeylerini kronik post-cerrahi ağrı prevelansı ile ilişkilendiren kapsamlı kanıtlara dayanarak epidural anestezi uygulanan hastalarda erken VAS skorlarının anlamlı olarak daha düşük olduğunu bulmamız epidural anestezinin kronik ağrıyı da azaltabileceğini göstermektedir (4). Hastalara epidural ilaç uygulamasıyla daha düşük VAS skorları, daha hızlı mobilizasyon, daha az postoperatif komplikasyon ve daha düşük kronik ağrı oranlarının elde edilmesi sağlanabilir. Bu sayede hastane maliyetlerinde ciddi azalma sağlanmış olur.

Literatürde batın cerrahilerinde epidural katater ile analjezi uygulamasının intraoperatif dönemde daha dengeli hemodinamiye ve daha az opioid tüketimine yol açtığını bildiren çalışmalar olmasına rağmen bazı çalışmalarda ise herhangi bir fark olmadığı bildirilmiştir (15-16). Çalışmamızda da epidural katater uygulanan grupta uygulanmayan gruba göre daha dengeli hemodinami ve daha az opioid tüketimi olduğunu saptadık.

Carli ve arkadaşlarının yaptığı bir çalışmada elektif kolon cerrahisi geçirecek 64 hastaya IV analjezi ve epidural analjezi uygulanmış ve mobilizasyon süresi epidural analjezi uygulananlarda daha kısa bulunmuştur (21). Yine iki grup arasında hastanede kalış süresi ve komplikasyon oranı benzer bulunmuştur. Bizim çalışmamızda da mobilizasyon süresi epidural uygulanan grupta daha kısa saptandı.

\section{Çalışmanın sınırlılıkları;}

Hasta sayısının az olması çalışmamızın sınırlamalarındandır. Maliyet analizinin yapılmamış olması çalışmamızın bir diğer sınırlamasıdır. Kronik ağrının değerlendirilmemesi başka bir sınırlamamızdır

Çalışma sonuçlarımız gösterdi ki gastrointestinal malignite nedeniyle cerrahi yapılan hastalarda epidural uygulaması daha az opioid tüketimine, daha düşük VAS skorlarına, daha yüksek aldrete skorlarına ve daha erken mobilizasyon süresine yol açmaktadır.

Sonuç olarak gastrointestinal malignite cerrahisi geçirecek olgularda genel anesteziye ek olarak epidural analjezi uygulamasında; hemodinamik stabilizasyon, erken derlenme, güçlü analjezik etki ve düşük yan etki profilinin yanısıra postoperatif erken mobilizasyon saptadık. Bu nedenle batın cerrahisi geçirecek hastalarda postoperatif ağrı kontrolünde multimodal analjezi yönteminin bir bileşeni olarak epidural katater ile analjezi uygulamasının faydalı olacağı kanaatindeyiz. Ancak intraoperatif anestezik ajan kullanımının ve maliyet analizinin eklendiği daha geniş hasta popülasyonu ile yapılan klinik çalışmalarla literatürün desteklenmesi gerektiğini düşünmekteyiz.

Etik Kurul Onayı: Sağlık Bilimleri Üniversitesi Diyarbakır Gazi Yaşargil Eğitim ve Araştırma Hastanesinden yerel etik kurul onayı alındı (28.12.2018 tarih 202 sayı). Bu çalışma Helsinki Deklarasyonu 2008 kriterlerine uygun olarak yapılmıştır.

Bilgilendirilmiş Onam: Katılımcılardan yazılı onam alınmıştır. 
Çıkar Çatışması: Yazarlar çıkar çatışması beyan etmemişlerdir.

Finansal Destek: Yazarlar finansal destek beyan etmemişlerdir.

\section{KAYNAKLAR}

1. PCA, regional and other local anaesthetic techniques, Acute Pain Management: Scientific Evidence. 20103 rd Edn Australia and New Zealand College of Anaesthetists and Faculty of Pain Medicine, 2013; 175224.

2. Brull R, MacFarlane AJR, Chan VWS. Spinal, epidural, and caudal anesthesia. In: Miller RD, ed. Miller's Anesthesia. 8th ed. Philadelphia, PA: Elsevier Saunders, 2015; 56.

3. Sherwood ER, Williams CG, Prough DS. Anesthesiology principles, pain management, and conscious sedation. In: Townsend CM, Beauchamp RD, Evers BM, Mattox KL, eds. Sabiston Textbook of Surgery. 19th ed. Philadelphia, PA: Elsevier Saunders, 2012; 16.

4. Breivik H, McMahon SB, Koltzenburg M. Local anesthetic blocks and epidurals. Melzack's Textbook of Pain. 5th ed. London: Elsevier-Churchill Livingstone, 2006; 903-25.

5. Pasero C, Portenoy RK, McCaffery M. Opioid analgesics. In: Pasero C, McCaffery M, eds. Pain Assessment and Pharmacologic Management. St. Louis, MO: Mosby, 2011; 125-29.

6. Macintyre PE, Schug SA. Acute Pain Management. 3rd ed. Edinburgh: Saunders Elsevier, 2007; 1-7.

7. World Health Organization. The World Health Report 2003. Geneva: WHO, 2003.

8. Bernard CM. Epidural and spinal anesthesia. In: Barash PG, Cullen BF, Stoelting RK, Cahalan MK, Stock MC, eds. Clinical Anesthesia. 6th ed. Philadelphia, PA: Lippincott Williams \& Wilkins, 2009; 127-9.

9. Erdine S. Postoperatif ağrı tedavisi. Erdine $S$ (Editör). Ağrı'da. İkinci baskı. İstanbul: Nobel Tıp Kitabevleri, 2002; 118-35.

10. Broekema AA, Veen A, Fidler V, Gielen MJ, Hennis PJ. Postoperative analgesia with intramuscular morphine at fixed rate versus epidural morphine or sufentanil and bupivacaine in patients undergoing major abdominal surgery. Anesth Analg 1998; 87:1 346-53.
11. Carli F, Trudel JL, Belliveau P. The effect of intraoperative thoracic epidural anesthesia and postoperative analgesia on bowel function after colorectal surgery: a prospective, randomized trial. Dis Colon Rectum 2001; 44: 1083-9.

12. De Beer JV, Winemaker MJ, Donnelly GA et al. Efficacy and safety of controlledrelease oxycodone and standard therapies for postoperative pain after knee or hip replacement. Can J Surg 2005; 48(4): 277-83.

13. Kehlet $H$, Dahl JB. The value of multimodal or balanced analgesia in postoperative pain treatment. Anesthesia \& Analgesia 1993; 77(5): 1048-56.

14. Jin F, Chung F. Multimodal Analgesia for postoperative pain control. Journal of Clinical Anesthesia 2001; 13: 524-39.

15. Erdaloğlu P. Jinekolojik Abdominal Cerrahilerde Peroperatif Deksmedetomidin Verilmesi ile Yara Yerine Levobupivakainin İnfüzyonunun Ağrıya Etkilerinin Karşılaştırılması (Uzmanlık Tezi). G.Ü.T.F, 2012.

16. Üstün B. Genel Anestezi Altında Major Abdominal Cerrahi Uygulanan Olgularda Torasik Epidural Analjezinin Hemodinami, Derlenme ve Postoperatif Analjezi Üzerine Etkileri (Uzmanlık Tezi). Trakya Üniversitesi Anesteziyoloji Anabilim Dalı, 2007.

17. Alagöz A, Günal $H$, Şavkıloğlu $E$, Göktaş $U$, Uluçınar $E$. Göğüs cerrahisinde torakal epidural analjezinin hemodinami, glukoz ve kortizol düzeyleri üzerine etkilerinin değerlendirilmesi. Anestezi dergisi 2005; 13(1): 31-6.

18. Özdilmaç I, Altıntaş F, Salihoğlu Z, Demiroluk Ş, Aydın S, Uzun H. Alt batın cerrahisinde genel enestezi ile epidural+genel anestezi uygulamasının stres yanıta etkileri. Anestezi Dergisi 2003; 11(3): 195-200.

19. Tulgar S, Selvi O, Kapakli MS. Erector spinae plane block for different laparoscopic abdominal surgeries: case series. Anesthesiology 2018; 1-3.

20. Gan TJ. Poorly controlled postoperative pain: prevalence, consequences, and prevention. J Pain Res 2017; 10: 2287-98.

21. Carli F, Phil M, Mayo N. Et al. Epidural analgesia enhances fonctional exercise capacity and Healtyrelated Quality of life after colonic surgery. Anaesthesiology 2002; 97: 540-9. 
Table 1. Hastaların klinik değerlerine göre dağılımları

\begin{tabular}{lcc}
\hline & $\mathbf{N}$ & Mean \pm SD \\
\hline Yaş, yıl & 28 & $58,7 \pm 12,3$ \\
BMI & 28 & $24,3 \pm 4,4$ \\
ASA Skoru (I/II/III), $\mathbf{n}$ & 28 & $1 / 16 / 9$ \\
Cinsiyet (Erkek/kadın), $\mathbf{n}$ & 28 & $14 / 14$ \\
Komorbidite (Var/Yok), $\mathbf{n}$ & 28 & $13 / 15$ \\
\hline
\end{tabular}

Table 2. Hastaların intraoperatif özellikleri ve postoperatif sonuçları (Mean \pm SD)

\begin{tabular}{|c|c|c|c|}
\hline & $\begin{array}{l}\text { Epidural Uygulanan } \\
\qquad(n=14)\end{array}$ & $\begin{array}{l}\text { Epidural Uygulanmayan } \\
\qquad(n=14)\end{array}$ & $P$ değeri \\
\hline Anestezi Süresi & $202,1 \pm 86,1$ & $286,4 \pm 113,9$ & $0.021 *$ \\
\hline Operasyon Süresi & $174,2 \pm 84,5$ & $251,7 \pm 109,7$ & $0.044^{*}$ \\
\hline Mobilizasyon Süresi & $12,36 \pm 2,8$ & $24,71 \pm 3,1$ & $0.000 *$ \\
\hline Aldrete Skoru 10. dk. & $7,79 \pm 0,8$ & $6,71 \pm 0,46$ & $0.001 *$ \\
\hline Aldrete Skoru 20. dk. & $8,79 \pm 0,6$ & $7,64 \pm 0,4$ & $0.000^{*}$ \\
\hline Aldrete Skoru 30. dk. & $9,14 \pm 0,5$ & $8,36 \pm 0,4$ & $0.002^{*}$ \\
\hline VAS Değeri 30. dk. & $3,0 \pm 0,8$ & $6,29 \pm 0,6$ & $0.000 *$ \\
\hline VAS Değeri 1. saat & $2,93 \pm 0,8$ & $5,79 \pm 1,0$ & $0.000 *$ \\
\hline VAS Değeri 2. saat & $2,64 \pm 0,9$ & $5,00 \pm 1,1$ & $0.000 *$ \\
\hline VAS Değeri 6. saat & $2,36 \pm 0,6$ & $4,64 \pm 0,7$ & $0.000 *$ \\
\hline VAS Değeri 12. saat & $1,79 \pm 0,6$ & $4,00 \pm 0,8$ & $0.000 *$ \\
\hline VAS Değeri 24. saat & $1,29 \pm 0,6$ & $3,71 \pm 0,6$ & $0.000 *$ \\
\hline VAS Değeri 48. saat & $1,14 \pm 0,5$ & $3,29 \pm 0,9$ & $0.000 *$ \\
\hline Opioid Tüketimi & $100 \pm 0,0$ & $246,4 \pm 21,5$ & $0.000^{*}$ \\
\hline Taburculuk Gün & $10,14 \pm 7,2$ & $11,93 \pm 7,91$ & 0.511 \\
\hline
\end{tabular}


Table 3. Hastalarda epidural uygulanan ve uygulanmayanların sistolik arter basınç değerleri ortalamalarına göre dağılımları (Mean \pm SD)

\begin{tabular}{|c|c|c|c|}
\hline & $\begin{array}{l}\text { Epidural Uygulanan } \\
\qquad(n=14)\end{array}$ & $\begin{array}{l}\text { Epidural Uygulanmayan } \\
\qquad(n=14)\end{array}$ & P değeri \\
\hline İndüksiyon Öncesi & $142,3 \pm 42,2$ & $134,5 \pm 37,9$ & 0.382 \\
\hline İndüksiyon Sonrası & $110,7 \pm 21,1$ & $102,5 \pm 18,1$ & 0.370 \\
\hline Entübasyon Sonrası & $126,5 \pm 39,2$ & $140,7 \pm 20,7$ & 0.565 \\
\hline Cilt İnsizyonu Sonrası & $123,6 \pm 17,7$ & $144,5 \pm 13,0$ & $0.003 *$ \\
\hline Operasyonun 30. dk. & $112,7 \pm 35,3$ & $107,3 \pm 51,6$ & 0.662 \\
\hline Operasyonun 60. dk. & $118,2 \pm 17,1$ & $129,3 \pm 12,9$ & 0.123 \\
\hline Operasyonun 120. dk. & $115,0 \pm 13,4$ & $128,9 \pm 15,3$ & $0.039 *$ \\
\hline Ekstübasyon Sonrası & $139,3 \pm 18,4$ & $154,0 \pm 15,7$ & $0.031 *$ \\
\hline
\end{tabular}

Table 4. Hastalarda epidural uygulanan ve uygulanmayanların diastolik arter basınç değerleri ortalamalarına göre dağılımları (Mean \pm SD)

\begin{tabular}{|c|c|c|c|}
\hline & $\begin{array}{l}\text { Epidural Uygulanan } \\
\qquad(n=14)\end{array}$ & $\begin{array}{l}\text { Epidural Uygulanmayan } \\
\qquad(n=14)\end{array}$ & P değeri \\
\hline İndüksiyon Öncesi & $83,0 \pm 11,3$ & $82,2 \pm 10,5$ & 0.818 \\
\hline İndüksiyon Sonrası & $65,6 \pm 13,6$ & $64,7 \pm 16,4$ & 0.713 \\
\hline Entübasyon Sonrası & $81,0 \pm 12,9$ & $84,5 \pm 14,2$ & 0.612 \\
\hline Cilt İnsizyonu Sonrası & $68,2 \pm 14,6$ & $81,2 \pm 9,0$ & $0.009 *$ \\
\hline Operasyonun 30. dk. & $67,5 \pm 14,3$ & $79,0 \pm 10,1$ & $0.032 *$ \\
\hline Operasyonun 60. dk. & $67,8 \pm 13,3$ & $76,5 \pm 10,9$ & $0.045 *$ \\
\hline Operasyonun 120. dk. & $67,9 \pm 6,5$ & $74,2 \pm 16,4$ & 0.243 \\
\hline Ekstübasyon Sonrası & $72,2 \pm 12,5$ & $81,5 \pm 10,3$ & $0.043^{*}$ \\
\hline
\end{tabular}


Table 5. Hastalarda epidural uygulanan ve uygulanmayanların kalp atım hız değerleri ortalamalarına göre dağılımları (Mean \pm SD)

\title{
Epidural Uygulanan
}

$(n=14)$

Epidural Uygulanmayan

P değeri

\begin{tabular}{|c|c|c|c|}
\hline & $(n=14)$ & $(n=14)$ & \\
\hline İndüksiyon Öncesi & $98,0 \pm 13,3$ & $86,2 \pm 11,6$ & $0.031 *$ \\
\hline İndüksiyon Sonrası & $90,7 \pm 12,3$ & $87,2 \pm 14,5$ & 0.476 \\
\hline Entübasyon Öncesi & $91,7 \pm 24,5$ & $92,7 \pm 12,9$ & 0.490 \\
\hline Cilt İnsizyonu Sonrası & $90,2 \pm 12,2$ & $85,7 \pm 13,5$ & 0.290 \\
\hline Operasyonun 30. dk. & $87,0 \pm 11,1$ & $84,8 \pm 15,0$ & 0.395 \\
\hline Operasyonun 60. dk. & $83,2 \pm 13,3$ & $79,2 \pm 12,8$ & 0.461 \\
\hline Operasyonun 120. dk. & $77,1 \pm 15,1$ & $80,2 \pm 11,7$ & 0.544 \\
\hline Ekstübasyon Sonrası & $86,0 \pm 10,3$ & $89,5 \pm 14,4$ & 0.597 \\
\hline
\end{tabular}
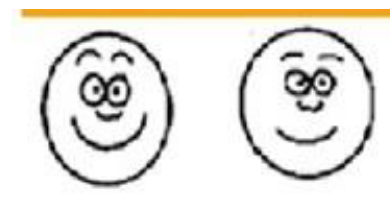

$$
0
$$

No Pain

\begin{abstract}
1
\end{abstract}
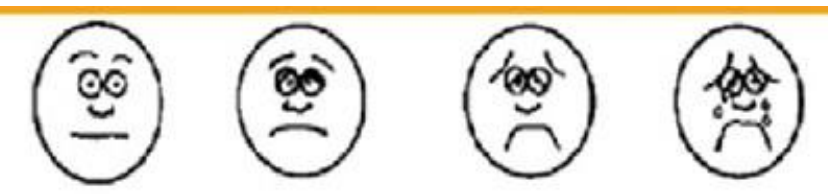

2

3

4

5

More

Rather Than

Most Severe

Resim 1. Vizüel Analog Skala

\begin{tabular}{|c|c|c|}
\hline Aktivite & $\begin{array}{l}4 \text { ekstremite } \\
2 \text { ekstremite } \\
0 \text { ekstremite }\end{array}$ & $\begin{array}{l}2 \text { puan } \\
1 \text { puan } \\
0 \text { puan }\end{array}$ \\
\hline Solunum & $\begin{array}{l}\text { Derin soluk alabilme ve rahat öksiurebilme } \\
\text { Dispneik, yüzeyel ve zorlu soluma } \\
\text { Apneik }\end{array}$ & $\begin{array}{l}2 \text { puan } \\
1 \text { puan } \\
0 \text { puan }\end{array}$ \\
\hline Dolaşım & $\begin{array}{l}\text { Normal değerden sapma }<\% 10 \\
\text { Normal değerden sapma }<\% 11-20 \\
\text { Normal değerden sapma }>\% 21\end{array}$ & $\begin{array}{l}2 \text { puan } \\
1 \text { puan } \\
0 \text { puan }\end{array}$ \\
\hline Bilinç & $\begin{array}{l}\text { Tam uyanik } \\
\text { Verbal uyariya refleks yanit var } \\
\text { Verbal uyarrya refleks yanıt yok }\end{array}$ & $\begin{array}{l}2 \text { puan } \\
1 \text { puan } \\
0 \text { puan }\end{array}$ \\
\hline Cilt rengi & $\begin{array}{l}\text { Oda havasında } \mathrm{SpO}_{2}>\% 92 \\
\mathrm{SpO}_{2}>\% 90 \text { olabilmesi için } \mathrm{O}_{2} \text { desteği gerekli } \\
\text { Sürekli } \mathrm{O}_{2} \text { desteği ile } \mathrm{SpO}_{2}<\% 92\end{array}$ & $\begin{array}{l}2 \text { puan } \\
1 \text { puan } \\
0 \text { puan }\end{array}$ \\
\hline
\end{tabular}

Resim 2. ALDRETE derlenme skorlaması 